\title{
Tax Reform dan Kendalanya
}

\author{
Budi Santoso Handoyo
}

\begin{abstract}
Abstrack
Attempt of taxation reform in Indonesia can be said to have occurred twice. The first reform took place in 1983, and constituted an extraordinary reform inasmuch as it update all Dutch-colonial inheritance taxation system. Ten years later, the second tax reform occurred, and it attempted to perfect the tax laws and regulations which had existed since 1983. This was due to the occurrence of perfection in all aspects of taxation laws and regulations including KUP, PPN, PPH, and PPB. However, to execute all results of the aforementioned reform is difficult. Various abstracles to implement a taxation system after the effectiveness of the taxation reforms can be found. Indeed, a strong and good will is required to settle those barriers. Thus, Indonesia can be developed on the basis of funding resulting from taxes.
\end{abstract}

\section{Pendahuluan}

Gambaran pajak sebagai topik yang tidak populer tidak hanya dialami oleh Indonesia saja, melainkan juga di negara-negara lain baik yang sudah maju maupun negara berkembang. Masyarakat dan pengusaha yang menjadi subjek pajak enggan membayar pajak dan menganggap pajak sebagai beban.

Pada sisi yang yang berbeda, rumah tangga negara semakin menggalakkan penerimaan pajaknya untuk menutup sektor lain yang tidak dapat memenuhi target dalam pendapatannya. Kalau diamati, perkiraan akan memudarnya sinar terang dari penerimaan minyak dan gas bumi (Migas), maka mulai sekitar tahun 1980/1981, Pemerintah menggalakkan sumber penerimaan dari sektor migas.

Tekad pemerintah ini menjadi sangat transparan dengan semakin menonjolnya peranan penerimaan pajak dalam penyusunan Rencana Anggaran dan Belanja Negara (RAPBN) pada beberapa tahun terakhir ini terutama dengan semakin menggalakkan pendapatan dari Pajak Pertambahan Nilai (PPN), Pajak Penghasilan (PPh).

Untuk mendukung ke arah penerimaan pendapatan dari sektor pajak secara optimal, pemerintah mencanangkan adanya reformasi perpajakan pada tahun 1983.

Sebenarnya kebutuhan untuk melakukan reformasi ini sudah tertanam sejak lama. Tetapi mengingat masalah pajak pada masa lalu telah memberikan citra buruk bahkan semacam trauma pada masyarakat Indonesia, maka upaya reformasi ini baru dimulai pada tahun 1983. Hal ini dilakukan mengingat kondisi masyarakat sudah lebih siap untuk diajak membangun bangsa dengan 
mengedepankan sektor pajak sebagai modal utama.

Sebenarnya Indonesia dapat dimaklumi apabila sebagai masyarakat Indonesia ada yang trauma dengan pajak. Dari sisi sejarah, dapat dilihat bahwa selama beratus-ratus tahun bangsa Indonesia berada dalam kekuasaan penjajah, sehingga pajak dikelola untuk memenuhi kepentingan penjajah. Oleh karena itu berbagai macam pergolakan dan pemberontakan muncul untuk menentang penarikan pajak yang dilakukan oleh penjajah.

Pajak kemudian menjadi pengalaman yang traumatik dan dijadikan sebagai salah satu cara agitasi untuk melawan penjajah Belanda.

Upaya reformasi pajak di Indonesia dapat dikatakan telah terjadi dua (2) kali. Reformasi yang pertama terjadi tahun 1983. Reformasi 1983 ini merupakan reformasi yang luar biasa hebatnya karena membongkar semua sistem perpajakan warisan kolonial Belanda. Sepuluh tahun kemudian, reformasi yang kedua terjadi yaitu pada tahun 1994. Reformasi yang.kedua ini merupakan penyempurnaan peraturan perundangan perpajakan yang sudah ada sejak tahun 1983. Dikatakan sebagai reformasi karena terjadi penyempurnaan yang hampir menyeluruh terhadap ketentuan perpajakan mulai dari KUP, PPN, PPh dan PBB.

Apabila melihat kilas balik perpajakan, maka dapat ditelusuri adanya berbagai pengkajian, penelitian yang diadakan sejak tahun 1981 yang bertujuan untuk mempersiapkan peraturan perpajakan. Baru pada akhir tahun 1983 bangsa Indonesia dapat mengganti sistem perpajakan peninggalan kolonial-dengan Pembaharuan Sistem Perpajakan Nasional (PSPN). PSPN ini terdiri dari dua paket. Paket I terdiri dari 3 UU yaitu
UU No. 6. tahun 1983 tentang Ketentuan Umum dan Tata Cara Perpajakan (KUTAP), UU,No. 7 tahun 1983 tentang. Pajak Penghasilan dan UU No. 8 tahun 1983 tentang Pajak Pertambahan Nilai dan Jasa dan Pajak atas Penjualan Barang Mewah (PPN BM). Paket II berisi dua UU yaitu UU No. 12 tahun 1985 tentang Pajak Bumi dan Bangunan (PBB) dan UU No. 13 tahun 1985 tentang Bea Materai.

Setelah PSPN berusia lebih dari 10 tahun, kembali diadakan penyempurnaan sistem perpajakan. Penyempurnaan ini bertujuan untuk mewujudkan keadilan dalam bidang perpajakan dan menyesuaikan dengan perkembangan dan kemajuan dalam bidang ekonomi dan perdagangan. Penyempurnaan sistem perpajakan baru ini ditandai dengan adanya perubahan-perubahan atas UU No. 6 tahun 1983, UU 7 tahun 1983, UU 8 tahun 1983 dan UU 12 tahun 1985. Penyempurnaan atas UU di atas diakomodir dalam:

1. UU No. 9 tahun 1994 tentang Perubahan atas UU No. 6 tahun 1983 tentang ketentuan Umum dan Tata Cara Perpajakan.

2. UU No.10 tahun 1994 tentang Perubahan atas UU No.7 tahun 1983 tentang Pajak Penghasilan.

3. UU No. 11 tahun 1994 tentang Perubahan atas UU No.8 tahun 1983 tentang Pajak Pertambahan Nilai Barang dan Jasa dan Pajak Penjualan Atas Barang Mewah.

4. UU No.12 tahun 1994 tentang Perubahan atas UU No.12 tahun 1985 tentang Pajak Bumi dan Bangunan.

Dilihat dari sistemnya, sistem perpajakan yang berlaku sebelum pembaharuan adalah 
sistem perpajakan yang dibuat pada jaman Belanda, seperti Ordonansi Pajak Kekayaan 1932 dan Ordonansi Pajak Pendapatan 1944. Dari sistem yang berbeda ini, maka landasan pemikiran, tujuan dan cara pelaksanaan pemungutan pajak di jaman kolonial sangat jauh berbeda dengan perpajakan pada jaman kemerdekaan. Pada masa kemerdekaan, perpajakan dijiwai oleh semangat yang ada dalam UUD 1945 dan Pancasila. Dengan demikian, pajak merupakan wujud partisipasi masyarakat dalam pembangunan.

'Dalam peráturan perundangán pajak jaman kolonial terdapat beberapa permasalahan yang sekaligus merupakan kelemahan; sehingga memerlukan pembenahanpembenahan yang mendasar. Kelemahankelemahan ini tercermin pada banyak hal.

Pertama, terdapat peraturan pajak yang beraneka ragam, sehingga menimbulkan kesan membingungkan dan banyak terjadi pajak ganda.

Kedua, pelaksanaan kewajiban pajak sangat tergantung pada aparat perpajakan sehingga. menimbulkan kecenderungan masyarakat wajib pajak kurang turut bertanggung jawab dalam memikul beban negara demi kepentingannya.sendiri dalam bermasyarakat, berbangsa dan bernegara.

Ketiga, terdapat berbagai jenis pajak, sehingga, menimbulkan ketidakjelasan bagi masyarakat dalam memenuhi kewajibannya.

Keempat, terdapat bermacam-macam tarif pajak baik untük perorangan maupun untuk perseroan dan juga bermacam-macam tarif dalam pajak penjualan di samping adanya tarif khusus untuk koperasi, perusahaan yang go publik dan perusahaan yang diperiksa oleh akuntan publik. Kesemuanya ini menimbulkan persaingan yang tidak sehat.
Kelima, struktur tarif yang progresif menimbulkan rangsangan bagi i wajib pajak untuk menyelundupkan pajaknya dengan berbagai cara. Pada akhirnya penerapan sistem progresif ini tidak dapat berjalan secara baik:

Keenam, tata cara pemungutan pajakpun' berbelit-belit."

Dalam usaha menyesuaikan dengan situasi ekonomi dan politik, sebelum pembaharuan sistem perpajakan pada tahun 1983, telah dilakukan beberapa perbaikan ala: kadamya. Perbaikan ini antara lain dituangkan dalam UU tahun 1967 sebagai pembenahan terhadap Pajak Pendapatan tahun 1944 dan beberapa perubahan lainnya.

Walaupun demikian, pembenahan ini. belum mampu menampung aspirasi masyarakat yang menjadi objek pajak. Bahkan kondisi yang lebih parah terjadi yaitu sampailah pada titik jenut di mana terdapat UU dan peraturan yang simpang siur, sehingga mengakibatkan pelaksanaan pérpajakan. menjadi birokratis. Efisiensi dan efektivitas' dalam proses dan hasil pun belum memenuhi. harapan.

Dalam sistem perpajakan pra 'reformasi ini adá satu hal yang dapat dicatat yaitu lancarnya , pemungutan pajak " dari perusahaan-perusahaan minyak: Sedangkan pemungutan pajak di luar bidang itu. tidak memberikan hasil yang maksimal. Masih rawan manipulasi, banyak insentif untuk hal yang tidak efisien dan banyak pémborósan.

Adapun tujuan yang hendak dicapai oleh pemerintah Indonesia dengan mengadakan tax reform ini adalah mewujudkan kesederhanaan dalam sistem perpajakan, meniadakan pajak berganda, pemerataan dalam pengenaan dan pembebanan, 
memberikan kepastian hukum, menutup peluang untuk menggelapkan pajak dan penyalahgunaan wewenang dan untuk mendorong kegiatan ekonomi dan bisnis.

Akan tetapi untuk mewujudkan tujuantujuan diatas tidaklah mudah, berbagai kendala menghadang untuk mewụjudkan sistem perpajakan setelah berlakunya tax reform dan membutuhkan tekad kuat untuk menyingkirkannya. Semua kendala yang ada harus disingkirkan apabila ingin membangun dengan berdasarkan pendanaan dari pajak.

\section{Sistem Perpajakan pada Tax Reform}

Kebutuhan untuk melakukan pembaharuan perpajakan sebenarnya sudah ada sejak lama. Namun mengingat kondisi masyarakat Indonesia yang masih trauma pada kondisi pajak pada masa kolonial, mengharuskan Pemerintah. bersabar dan menunda pembaharuan pajak ini pada tahun 1983. Pada tahun 1983 Pemerintáh menganggap masyarakat sudah mampu menghilangkan trauma dan bersedia diajak ikut serta di dalam pembangunan dengan cara membayar pajak.

Trauma masyarakat terhadap pajak ini kiranya dapat dimengerti. Selama 350 tahun dibawah penjajahan Belanda, pemungutan pajak dipaksakan oleh penjajah dan digunakan untuk kepentingan pemerintah kolonial. Pajak kemudian digunakan sebagai salah satu alat untuk melawan' Belanda.

Setelah Indonesia merdeka, pemerintah menyadari bahwa masyarakat harus diajak berpartișipasi aktif dalam pembangunan. melalui cara aktif membayar pajak. Untuk mendukung hal ini, pemerintah berusaha mengganti sistem perpajakan kolonial yang tidak sesuai bagi bangsa Indonesia setelah merdeka.

Baru pada tahun 1983, pemerintah berhasil melakukan pembaharuan perpajakan yang dikenal dengan Pembaharuan Sistem Perpajakan Nasional (PSPN). Dalam menyusun sistem baru ini, pemerintah sangat memperhatikan tiga unsur dalam perpajakan yang sangat penting yaitu: kebijaksanaan perpajakan, hukum perpajakan dan administrasi perpajakan.

Kebijaksanaan perpajakan merupakan pemilihan unsur-unsur tertentu dari berbagai alternatif yang didasarkan atas sasaran yang ingin dicapai. Pemilihan unsur-unsur ini berkenaan dengan subjek pajak, objek pajak, tarif pajak dan prosedur pajak. Adapun yang dimaksud dengan subjek pajak adalah halhal yang berkenaan pemilihan tentang siapa yang dikenai pajak, sedangkan objek pajak merupakan penentuan pilihan tentang apa yang dikenai pajak. Sementara tarif pajak adalah cara menghitung besarnya pajak, apakah itu tarif proporsional, progresif, regresif dan lain= lain. Sedangkan prosedur pajak merupakan pemilihan tata cara pelunasan pajak yang terhutang, misalnya apakah menggunakan cara self assesment atau official assesment.

Hukum pajak yang dikenal juga dengan hukum fiskal adalah keseluruhan peraturan yang meliputi wewenang pemerintah untuk mengambil kekayaan seseorang dan menyerahkan kembali kepada masyarakat melalui Kas Negara, sehingga pajak merupakan bagian dari Hukum Publik yang mengatur hubungan hukum antara Negara dengan wajib pajak.'

'R.Santoso Brotodihardjo. 1984. Pengantar Ilmu Hukum Pajak,Eresco. Bandung. hal.1 
Adam Smith dalam bukunya Wealth of Nations, yang dikutip oleh Rochmat Soemitro, ${ }^{2}$ memberikan pedoman bahwa supaya peraturan pajak itu adil harus memenuhi empat syarat; yaitu equality; certainty; convenience of payment; dan economic of collection.

Sedangkan yang dimaksud dengan administrasi perpajakan adalah cara-cara dan prosedur pengenaan serta pemungutan pajak, di mana yang bertindak sebagai pelaku administrasi pajak di Indonesia adalah Dijen Pajak, Dirjen Bea Cukai dan Dirjen Moneter. Dengan demikian dapat dikatakan bahwa administrasi perpajakan merupakan tanggungjawab instansi pajak, yang disinyalir oleh United Nation Committee of Experts disekitar tahun 1970 sebagai salah satu kelemahan dalam sistem perpajakan di negara-negara berkëmbang. ${ }^{3}$

Setelah Tax Reform / tahun 1983, 10tahun kemudian pemerintah melakukan penyempurnaan UU Perpajakan tahun 1994. Arah Tax Reform. II, - inj adalah untuk mengakomodasikan kebijaksanaan investasi. dalam negeri, sehingga dapat menarik minat perusahaan PMA untuk menanamkan modalnya di Indonesia. Selain sebagai kebijakan dalam investasi, Tax Réform II, juga bertujuan untuk mengakomodasikan berbagai hal yang masih mengganjal pada Tax Reform 1. Tujuannya adalah jelas untuk memenuhi keadilan dalam perpajakan. Dalam skala yang paling luas, Tax Reform II ini merupakan perbaikan sistem dari Tax Reform I 1983.

Pelaksanaan UU No.6 tahun 1983 ternyata banyak mengadapi masalah, karena banyak hal yang belum diatur dalam UU tersebut. Oleh karena itu, pemerintah berusaha menutup kekurangan itu dengan mengeluarkan UU No.9 tahun 1994.

Dalam UU No.9 tahun 1994 ini, anggota masyarakat tetap diberikan kepercayaan untuk dapat melakukan gotong royong secara nasional dalam sistem menghitung, membayar, dan melaporkan pajaknya (self assesment); sehingga melalui sistem ini administrasi perpajakan diharapkan dapat dilaksanakan dengan rapi, terkendali, sederhana dan mudah dipahami oleh anggota masyarakat.

Walaupun sudah melalui penelitian, diskusi dan pembahasan yang mendalam, ternyata UU No.9 tahun 1994 ini masih mempunyai kelemahan yang mendasar. yang terdapat dalam Pasal 21 yaitu tentang hak mendahului dari negara. Menurut penulis, hak meridahului dari negara ini seharusnya. menyesuaikan dengan hak privelege pemegang gadai dan hak tanggungan. Hal ini. periu dikemukakan karena biasanya kreditur akan meminta jaminan yang berupa hak tanggungan atau gadai yang dapat segera dieksekusi apabila terjadi wanprestasi. Namun, apabila hak mendahului negara ini. berada di depan hak pemegang gadai dari hak tanggungan, -maka kemungkinan besar pemegang gadai dan hak tanggungan ini akan "gigit jari" apabila suatu badan usaha dinyatakan pailit dan hartanya hanya cukup untuk membayar pajak. Har ini rasanya bertentangan dengan rasa keadilan.

${ }^{2}$ Rochmat Soemitro. 1990. Asas dan Dasar Perpajakan 1, Eresco. Bandung. 1990. hal.15

${ }^{3}$ Moh. Zain dan Kustadi Arinta. 1990. Pembaharuan Perpajakan Nasional. Citra Aditya Bandung. hal. 107. 
Secăra kronologis, hak mendahului negara ini merupakan salah satu cara yang diterapkan oleh pemerintah untuk menangkal, kenakalan konglomerat yạng biasa meminjam uang dari banknya sendiri. Apabila hutang pada banknya sendiri, maka apabila bank menyita agunan, maka agunan sama saja kembali pada pemiliknya. Hak mendahului negara ini, memang dilematis. Satu pihak dapat menangkal wajib pajak yang nakal, tetapi justru dapat merugikan wajib pajak yang jujur.

Dalam UU ini ditetapkan bahwa pedoman penyelenggaraan pembukuan " atau. pencatatan ditetapkan oleh Dirjen Pajak. Tujuan dari ketentuan ini adalah untuk memberikan dasar hukum wewenang bagi. Dirjen Pajak untuk menyusun pedoman penyelenggaraan pembukuan atau pencatatan:

- Dalam SPT terdapat satu permasalahan yaitu- masalah pembetulan SPT. Hak fiskus menerbitkan ketetapan pajak diperpanjang dari 5 tahun menjadi 10 tahun. Hal ini dihádapkan: dengan hak WP melakukan koreksi hanya 2 tahun atau lebih dua tahun: sepanjang belum diterbitkan SKP. Hal ini kurang mencerminkan keseimbangan hak dan kewajiban antara fiskus dan WP. Wakti dua tahun ini menghambat WP yang ingin melakukan koreksi SPTnya dan membayar kekurangan pajak masa sebelumnya. Dilihat dari sisi penerimaan negara korekśi ini cukup menguntungkan fiskus.

Salah satu hal yang masih agak mengganggu dalam UU ini adalah masalah daluwarsa. Sebenarnya, secara hakiki sistem assesment ini tidak mempunyai batas waktu.
Diubahnya masa daluwarsa dari 5 menjadi 10 tahun merupakan kemunduran dan seolaholah merupakan sarana untuk memberikan "excuse". bagi kelemahan aparat.".

Masalah penurunan tarif pajak ternyata mempunyai dampak yang luas kareña memungkinkan perluasan obyek pajak secara sukarela yang akhirnya dapat meningkatkan penerimaan negara. Kiranya demi kepastian hukum di kemudian hari beberapa.kriteria pokok yang dapat mengubah tarif maksimum. PPh perlu dicantumkan. Hal ini mengingat perlunya konsistensi hukum sehingga tidak tergantung pada pribadi Menteri Keuangan yang sedang menjabat.

Satu kemajuan yang perlu dicatat adalah dimungkinkannya suami maupun istri menjadi wajib pajak sendiri. Dengan diturunkannya tarif $\mathrm{PPh}$, maka pemisahan wajib pajak ini akan memberikan keuntungan pada wajib pajak karena akan lebih sedikit membayar pajak.

Dalam rangka menunjang kebijakan pemerintah untuk meningkatkan pertumbuhan dan pemerataan, maka pemerintah melalui UU ini memberikan fasilitas perpajakan kepada WP yang menanamkan modalnya $\mathrm{di}$ daerah tertentu atau bidang usaha tertentu. Selain itu sesuai dengan kebijakan untuk pro lingkungan, ditegaskan bahwa pengolah. limbah dapat dibebankan sebagai biaya dan diatur mengenai. pembentukan atau pemupukan cadangan untuk reklamasi.

Untuk memberikan kemudahan kepada WP, UU ini memberikan kebebasan kepada WP untuk menghitung penyusutan atas harta yang dimiliki dan digunakan dalam usaha serta lebih menyelaraskan pembukuan WP untuk

${ }^{4}$ Mardiasmo Perpajakan. Andi Offset. Yogyakarta:hlm.17. 
kepentingan fiskal, maka kepada WP diberi keleluasaan untuk memilih metoda penyusutan atas harta benwujud bukan bangunan.

Dalam rangka kemudahan dan kesederhanaan pengenaan pajak serta untuk meningkatkan kepatuhan wajib pajak, diatur pemungutan pajak yang bersifat final atas penghasilan-penghasilan tertentu.

Pengaturan subjek pajak dalam UU ini lebih luwes dan dapat mengikuti perkembangan sosial ekonomi serta bentuk-bentuk aktivitas bisnis yang timbul dan berkembang dalam masyarakat. Ketentuan mengenai obyek pajak diatur lebih rinci, jelas dan tegas untuk lebih memberikan kepastian hukum dan keadilan dalam pengenaan pajak.

Pemerintah tampaknya cukup akomodatif dan berkenan menampung semua ketentuan yang secara formal tidak diatur dalam UU.PPN 1983 dan hanya diatur dalam PP maupun Keppres yang dianggap kurang memiliki landasan kuat dalam bidang hukum. Tetapi dari segi materi dan mengingat kemungkinan memberikan ruang fleksibilitas dalam pelaksanaan masih diperlukan peraturan pelaksana yang ditampung dalam PP, SK Menkeu atau SK Dirjen Pajak seperti kriteria pengusaha kecil, pengaturan barang dan jasa yang dibebaskan PPN atau yang PPN nya tidak dipungut.

Siștem pengkreditan pajak masukan.(PM) terdapat perubahan yang mendasar. Dengan tidak diperkenankan pengkreditan Pajak Masukan atas pembelian dan pemeliharaan barang modal, maka tujuan pokok diberlakukan UU.P.P.N 1983 yang semula mencegah pungutan -ganda, tidak dipertimbangkan-lagi, yang dampak ekonominya makro, khususnya dalam meningkatkan ekspor hampir dipastikan kurang menguntungkan karena akan menaikkan harga barang dan jasa.

Tarif pajak PPN yang berlaku atas penyerahan barang kena pajak adaiah tarif tunggal, sehingga memudahkan dalam pelaksanaan dan tidak memerlukan daftar penggolongan barang. Tarif pajak penjualan atas barang mewah tidak menganut sistem tarif tunggal dan diterapkan sesuai dengan kelompok barang yang dikenakan pajak penjualan atas barang mewah. Dalam rangka mendorong ekspor non migas, atas ekspor barang kena pajak dikenakan pajak dengan tarif $07,5 \%$. Oleh karena itu PPN yang dibayar karena perolehan barang kena pajak yang terkandung dalam barang kena pajak yang diekspor dapat dikompensasikan dan diminta kembali.

Untuk lebih meningkatkan perwújudan dan keadilan dalam pembebanan pajak' untuk menunjang peningkatan penanaman modal, pelestarian lingkungan hidup dan kebijakan lạin, WP perlu diperilakukan secara khusus. Namun demikian tidak boleh bertentangan dengan asas bahwa perpajakan dilakukan sama untuk semua wajib pajak. Oleh karenä itu setiap pemberian kemudahan dalam bidang perpajakan harus tetap mengacu pada kaidah-kaidah yang berlaku, sehingga maksud dan tujuan pemberian fasilitas itu dapat tercapai.

Perubahan yang paling mendasar dalam 12 tahun 1994 adalah diaturnya ketentuan tentang nilai jual objek pajak tidák kèna pajak untuk setiap wajib pajak. Ketentuan ini menguntungkan bagi petani yäng hanya mempunyai. tanah dan bangunan, karena pajak hanya dikenakan pada objek pajak yang nilainya di atas 8 juta rupiah. 
Kendala-keñdala dalam Pelaksanaan Tax Reform

Mengkaji kendala-kendảla dalam pelaksanaàn tax reform tidak dapat dilepaskan dari 'faktor-faktor yang' mempengarühi keberhasilan tax reform itu sendiri. Apabila diamati, maka keberhasilan peiaksanaan "tax reform ini tergantung pada empat faktor, yaitù:

\section{Faktor Sistem Perpajakan}

Untuk dapat mempunyai sistem perpajakan yang baik dan konsisten bukanlah pekerjaan yang mudah. Kendala-kendala yang sangat dipengaruhi oleh situasi umum . sangatlah banyak.

Dari segi peraturannya, dengan telah diundangkannya lima UU perpajakan pada tax reform, I (satu ) yang kemudian diperbaharui pada tahun 1994 dengan tax reform II, maka sesungguhnya sistem perpajakan di Indonesia sudah cukup kokoh. Kekokohan ini ditopang dengan prinsip-prinsip seperti kesederhanaan dalam sistem perpajakan, peniadaan pajak berganda, pemerataan dalam pengenaan dan pembebanan, memberikan kepastian hukum dan meminimalkan peluang untuk penggelapan pajak. Kiranya sangat berlebihan apabila kita mengharapkan sistem perpajakan yang sempurna.Sekalipun demikian, déngan bermodalkan prinsip-prinsip di atas ditambah dengan keterbukaan dan kepekaan pimpinan lembaga dalam menangani mașalah perpajakan, maka sistem dan aturan perpajakan yang dapat digunakan dengan sebaik-baiknya.

Berkaitan dengan sistem perpajakan ini, tidak dapat ditinggalkan adalah sumber daya manusia dalam arti aparatur pajak. Citra pajak sedikit banyak ditentukan oleh peraturannya.
Masyarakat seringkali enggan membayar pajak karena tidak mendapatkan pelayanań yang baik dari aparatur pajak. Biasanya kelambanan pelayanan, tidak jelasnya jalur birokrasi yang harus dilalui merupakan masalah klasik yang berkaitan dengan aparatur ini. Harus diakúi bahwa untuk membina aparatur pajak yang baik membutuhkan waktu yang lama. Usaha menciptakan perilaku panutan di bidang perpajakan harus sudah dimulai. Langkah kearah itu dapat dilaksanakan secara bertahap melalui tahap peningkatan mutu dan peningkatan mental.

\section{Faktor Sistem Penunjang}

Yang menjadi faktor sistem penunjang ini antara lain meliputi pembukuan, akuntansi, dan profesionalisme seperti management, komputer dan lain-lain.

Dari sistem penunjang ini, pembukuan merupakan faktor penting.-Untuk mengisi SPT $\mathrm{PPh}$, wajib pajak disamping harus menyelenggarakan pembukuan, harus pula melengkapinya dengan laporan keuangan berupa neraca dan perhitungan rugi laba serta keterangan lain yang diperlukan untuk menghitung besarnya penghasilan kena pajak.

Untuk dapat mengisi SPT seperti yang di syaratkan, tentunya memerlukan pembukuan yang tertib dan benar yang merupakan proses pencatatan yang teratur dari waktu ke waktu dan pengelolaan kejadian-kejadian dalam perusahaan. Pembukuan merupakan sarana informasi bagi wajib pajak untuk mengisi SPT secara benar dan lengkap.

Dalam praktiknya, pembukuan di perusahaan-perusahaan Indonesia tidaklah 
sebaik. yang diharapkan.. Kadang-kadang Perusahaan membuat beberapa pembukuan yang digunakan untuk tujuan yang berbeda. Misainya pembukuan . dengan melipatgandakan keuntungan yang digunakan untuk pihak bank, pembukuan yang meminimalkan . keuntungan dan memperbesar hutang yang ditujukan untuk petugas pajak dan pembukuan yang digunakan bagi kepentingan ilmiah seperti mahasiswa yang akan menyusun skripsi, tesis atau disertasi: Keadaan seperti ini jelas merupakan suatu kendala dalam pelaksanaan tax reform.

Dari sisi profesionalisme dan manajemen, keberadaan kantor-kantor pajak perlu kiranya. untuk ditambah. Hal ini sejalan dengan upaya pemerintah untuk memberikan pelayanan yang maksimal kepada wajib pajak. Banyaknya. kantor pajak akan memberikan kemudahan bagi wajib pajak untuk menyetorkan pajaknya. Namun dengan banyaknya kantor pajak harus didukung - pula ' dengan - kèmampuan manajerial yang baik, sehingga koordinasi antara bagian-bagian yang menangani pajak dapat berjalan dengan .lancar dan baik..$^{5}$.

\section{Faktor Masyarakat}

Dalam sistem perpajakan yang baru ini digunakan sistem self assesment yang berarti wajib pajak diberikan kepercayaan untuk menghitung, membayar sendiri pajak yang terhitung. Besarnya pajak yang dibayar dihitung sendiri oleh masyarakat untuk kemudian membayar pajak yang terhitung berdasarkan ketentuan peraturan perundangan. Semuanya ini dilakukan tanpa menggantungkan-adanya
Surat Ketetapan.Pajak.

Uńtuk mewujudkan self assesment ini memerlukan keuletan, waktu dan kerja keras dan rasa pengabdian yang tinggi. Karena rakyat Indonesia harus sadar bahwa tanggung jawab rakyat dalam pelaksanaan pembangunan adalah besar, semakin berat dan. semakin luas. Kesadaran ini merupakan faktor yang fundamental dalam pembangunan yang harus dikembangkan secara dini di dalam masyarakat. Apabila kesadaran masyarakat ini tidak dapat ditumbuhkan, maka pelaksanaan tax reform akan menghadaipikendala yang besar. Oleh karena itu, pemerintah dan masyarakat sebaiknya bahu membahu untuk mengubah perilaku perpajakan masyarakat yang kürang baik ke arah yang baik, juga meningkatkan yang sudah baik.

\section{Faktor Ekstern}

Selain tiga faktor diatas, ada faktor yang penting ... yang dapat mempengaruhi keberhasilan daląm pelaksanaan tax reform. Faktor itu adalah faktor ekstern. Faktor ekstern yang pertama adalah faktor ekonomi. Sejak tahun 1980, perekonomian Indonesia mengalami kelesuan. Hal ini mempengaruhi pendapatan masyarakat dan pengusaha. Disinilah tampak adanya keterkaitan antara faktor ekonomi dengan pajak.

Semakin baik kondisi ekonomi, maka penerimaan dari pajak akan beşar, sebaliknya apabila kondisi perekonomian sedang 'lesu, maka penerimaan pendapatan dari sektor pajäk akan menưun.

${ }^{5}$ Op.cit, Moh.Zain dan Kustadi Arinta, hal.110. 
Dari segi yang lain, secára soșial budaya masyarakăt Indoneșia màsih bersifat patronklieñ Sifat ini 'akan membawa pengaruh baik apabilä. sang patron (bapak/panutan) memberikan téladan yang baik dengan patuh membayar pajak karena merasa tidak enak. apabila tidak mengikuti perilaku patronnya. Hăl sebaliknya akan terjadi apabila patronnya tidak patuh membayar pajak. Disinilah fungsi keteladanan menjadi tampak nyata.

\section{Simpulan}

Dari uraian di atas, dapat ditarik beberapa kesimpulan dan sarän sebagai berikut:

1. Penerimaan pajak semakin mendapat porsi yang besar dalam penerimaan negara seperti yang tercantum dalam RAPBN.

2. Tax Reform membawa perubahan dalam sistem perpajakan di Indonesia. Perubahan sistem kolonial menjadi Sistem Nasional ditandai dengan adanya kesederhanaan; 'kepastian hukum, peniadaan pajak berganda serta' meminimalkan peluang urituk mengigelapkan pajjak. Selain itu pajak didorong sebagai alat untuk ikut serta, dalam pengembangan ekonomi.

3. Beberapa kendala yang dihadapi pemerintah dalam pelaksanaan tax reform ini adalah:
a. kendala dalam sistem perpajakan
b. kendala dalam sistem pènunjang;
c. kéndala dari masyarakat yang berupa ketidakpatuhan dalam membayar pajak
d. kendala ekstern seperti situasi ekonomi, sosial budaya dan lain-lain.

e. Pelaksanaan perpajakan yang efisien dan lebih efektif memerlukan pola dukungan organisasi, tata kerja dan personalia yang sebanding.

f. Penegakan UU Perpajakan baru ini harus lebih tegas sesuai dengan ketentuan yang berlaku sebagaimana juga: berlaku di bidang lainnya, maka

$\therefore$ metoda self assessment ini harus diikuti dengan kegiatan verifikatif, penagihan, auditing dan investigasi yang lebih sistematis dan ketat:

\section{Daftar Pustaka}

Brotodihardjo, Santoso, 1984, Pengantar IImu Hukum Pajak, Eresco, JakartaBandung. :

Mardiasmo, 1988, Perpajakan; Andi Offset, Yogyakarta.

Soemitro, Rochmat,1990, Asas dan Dasar

Perpajakan 1, Edisi Revisi, Eresco, Bandung.

\section{-_- 1988 , Pajak Ditinjau Dari Segi}

Hukum, Eresco, Bandung.

- 1987, Asas dan Dasar Perpajakan 2, Eresco, Bandung.

Zain, Mohammad, dan Arinta Kustadi, 1990, Pembaharuan Perpajakan Nasional, Citra Aditya Bakti, Bandung.

UU No. 6 tahun 1983 tentang Ketentuan Umum dan Tata cara Perpajakan.

UU No. 7 tahun 1983 tentang Pajak Penghasilan.

UU No. 8 tentang 1983 tentang Pajak Pertambahan Nilai Barang dan Jasa dan Pajak Penjualan Atas Barang Mewah. 
UU No. 12 tatiun 1985 tentang Pajak Bumi dan Bangunan.

UU No. 9 tahun 1994 tentang Perubahan atas UU No. 6 tahun 1983.

UU No. 10 tahun 1994 tentang Perubahan atas UU No.7 tahun 1983 tentang Pajak Penghasilan.
UUNo.11 tahun 1994 tentang Perubahar atas UU No 8 tahun 1983 tentang Pajak Pertambahan Nilai Barang dan Jasa dan Pajak atas Barang Mewah.

UU No. 12 tahun 1994 tentang Perubahan atas UU No. 12 tahun 1985 tentang Pajak Bumi dan Bangunan.

果 